
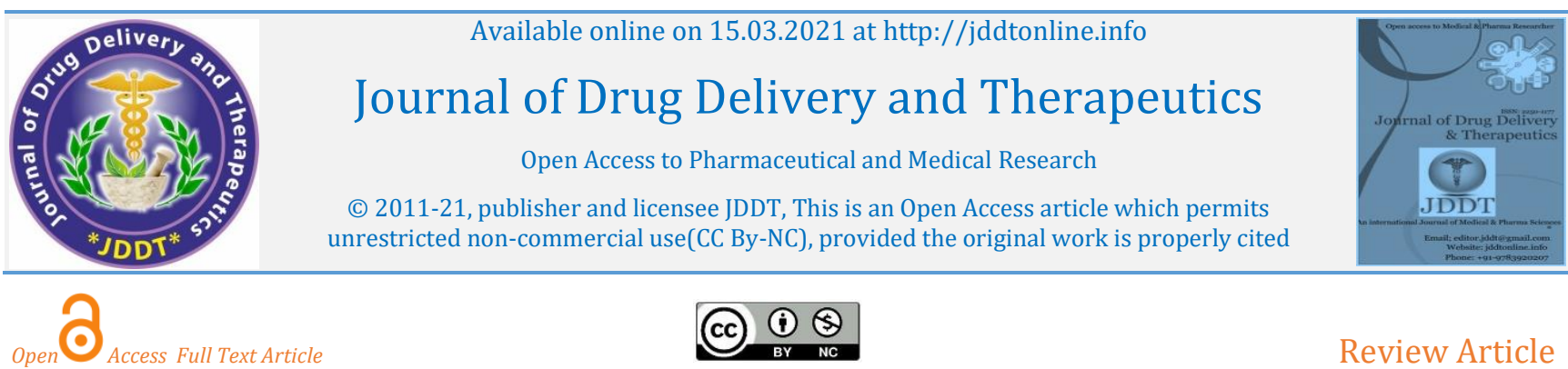

Review Article

\title{
Sibr (Aloe barbadensis): A Short Description with Unani Approach
}

\author{
Akhtar Hilal ${ }^{*}$, Akhtar Md. Wasi², Khan Md. Saad Ahmad ${ }^{3}$, Husain Syed Zeba ${ }^{4}$ \\ ${ }^{1}$ Assistant Professor, D/o Amraz-e-Jild wa Tazeeniyat, Allama Iqbal Unani Medical College \& Hospital, Muzaffarnagar, UP, India. \\ ${ }^{2}$ Assistant Professor, D/o Moalajat, School of Unani Medical Education and Research, Jamia Hamdard, New Delhi, India. \\ ${ }^{3}$ Assistant Professor, D/o Ilaj-bit-Tadbeer, A.K.Tibbiya College, AMU, Aligarh, India. \\ ${ }^{4}$ Private Unani Consultants, Aligarh, India.
}

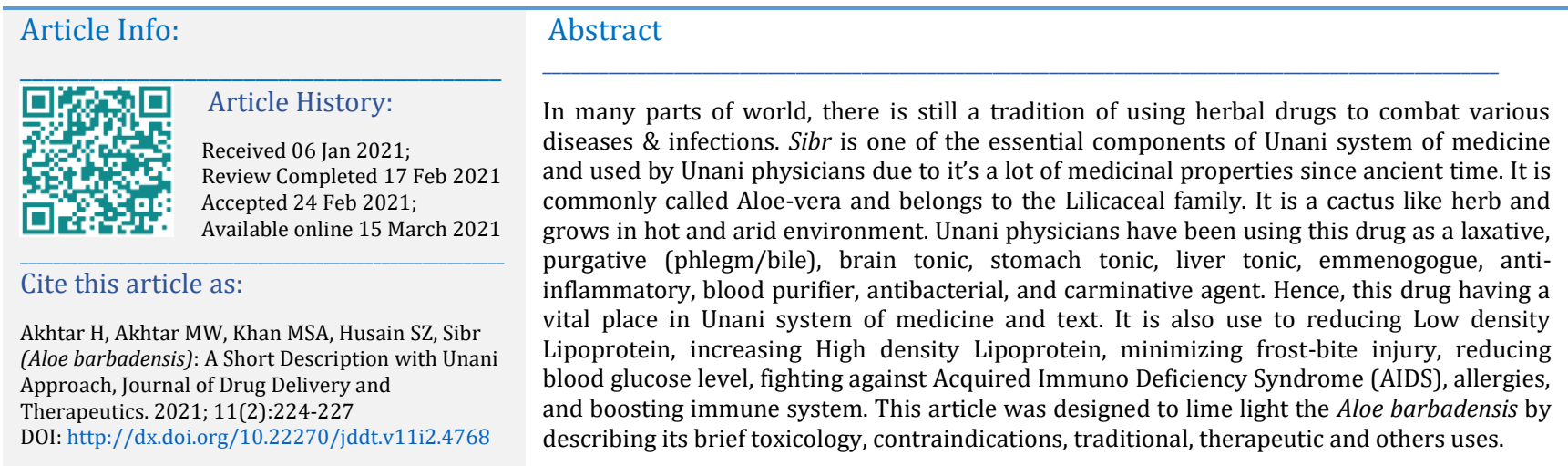

Keywords: Antibacterial, Aloe barbadensis, Sibr, therapeutic, Unani system of medicine.

*Address for Correspondence:

Hilal Akhtar, D/o Amraz-e-jild wa Tazeeniyat, Allama Iqbal Unani Medical College \& Hospital, Muzaffarnagar, UP, India.

\section{INTRODUCTION:}

Sibr (Aloe vera) is an extremely popular herbal drug amongst the various currently available herbal remedies and at the moment receiving a lot of scientific attention ${ }^{1}$. Sibr is an oldest medicinal plant ever known and most applied medicinal plant globally used for centuries for its health, beauty, cosmetic, vigor, wellness, and medicinal properties ${ }^{2,3}$. The name Aloe vera derives from the Arabic word "Alloeh," meaning 'shining bitter substance,' whereas "vera" in Latin means "true," about 2000 years back. The Unani scientists considered Sibr as the universal panacea and Egyptians called it "the plant of immortality." Nowadays, the plant of Sibr has been used for different purposes in Amraaz-e-jild Wa Tazeeniyaat (Dermatology and Cosmatology) ${ }^{3}$.

\section{HISTORY:}

The history of our understanding of $A$. barbadensis parallels the history of scientific knowledge. Sibr has been used for its medicinal properties in many cultures such as Greece, Egypt, India, Japan, China, and Mexico from thousand years. It is used by Egyptian Queens Nefertiti as beauty regimes. Dioscorides, renowned Unani scholar of Roman era, describe about the Sibr in his Medical treatise "De Materia Medica"3.

\section{BOTANICAL DESCRIPTION: 4}

\section{Taxonomy}

Kingdom: Plantae

Order: Asparagales

Family: Asphodelaceae (Liliaceae)

Genus: $\quad$ Aloe

Species: A. vera

\section{PLANT PROFILE:}

Botanical Name: Aloe barbadensis Linn.5,6

Common Name: Aloe Vera ${ }^{3}$

Family: Liliaceae $5,6,7$

\section{Vernacular Names:}

Arabic: Sibr 7,8 Persian: Shabyar, Alwa ${ }^{9}$ Hindi: Ailwa 5 Ghee-kanwar ${ }^{10}$ Greek: Faiqra ${ }^{9}$ Sanskrit: Kumarai, Aileekh 7,8 English: Indian aloes 7,8,10 Romi: Alya ${ }^{9}$ 


\section{Part Used}

The dried and fresh juice of the leaves, leaf gel, the whole leaves, the gel from the water storing tissue and the roots. $7,8,11$.

\section{Temperament (Mizaj):}

Hot and dry in second degree.5,7,8

Hot in second degree \& dry in third degree. $9,12,13$

\section{GEOGRAPHICAL DISTRIBUTION:}

There are about 250 species of $A$. barbadensis grown throughout the world. Amongst them 2 species are grown commercially e.g. A. barbadensis Miller and A. arborescens. It is grown in warm, tropical regions and cannot stay alive in freezing temperature ${ }^{1}$.

Aloe vera is a native to North Africa, the Mediterranean region of South Europe, Canary Island, Souther Arabia, and Madagascar. It is now cultivated throughout the West Indies, North and South Tropical America, Caribbean and tropical Asia $14,15,16$. In India, it grows wild on the coast of Mumbai, Gujarat, and South India ${ }^{17,18 .}$

\section{TRADITIONAL USES:}

It is popular amongst various traditional medicines like Chinese, Ayurvedic, Unani etc. In Ayurvedic medicine, it is used internally as a uterine stimulant, laxative, vermicide, and hemorrhoid remedy. Topically, it is used to treat various skin disorders like eczema, psoriasis in different proportion with licorice root. In Arabian medicine, the fresh gel of Aloe is rubbed on the forehead to lighten the headache and also rubbed on the whole body to cool it in case of pyrexia. It is also use to heal the wound, to cure the conjunctivitis and as a disinfectant ${ }^{19}$.

\section{ACTIONS (AFA'AL): 5,6,7,8,10,12,18,20,21,22,23}

Laxative/Cathartic, Purgative (Phlegm/Bile), Tonic to stomach and liver, Vermicide Emmenogogue, Antiulcerogenic, Anti-inflammatory, Anesthetic, Anti-bacterial, Anti-prostaglandin effect, Anti-spasmodic, Carminative, Diuretic, Blood Purifier, Antileprotic.

\section{THERAPEUTIC USES:}

Gastro-intestinal tract: Aloe relieves obstruction of liver and stomach, act as a tonic for liver \& stomach and is beneficial in jaundice.10,24,25. The drug is widely used for constipation, anal fissure, and haemorrhoids. $205,206,223$ It is used in worm infestation due to its vermicide action ${ }^{7,22}$. The stem is used in dysentery ${ }^{10}$.

Central Nervous System: It purifies the brain, eyes by excretion of corrupt humors from them. It is beneficial in melancholia and in case of headache it mixed with rose oil \& applied on forehead 24,25 .

Respiratory system: It is used in children suffering from bronchial asthma ${ }^{10,22,25}$.

Skin: Radiation burns, thermal burns, frost bite, wound healing in pressure sore, seborrhoeic dermatitis, and psoriasis ${ }^{9,10,20,25,26,27 .}$

\section{Fertility and Menstruation:}

In a study aloe compound was found to improve fertility in $85 \%$, the menstrual function also improved in $44.60 \%$. It has been concluded that aloe compound is very useful in case of functional sterility.28. It is also used in various menstrual disorders such as amenorrhea, oligomenorrhoea $7,8,22$.

\section{Analgesic Activity:}

Carboxypeptidase was found to have a significant analgesic effect and inhibited the acceleration of vascular permeability with acetic acid inflammation. It has been suggested that carboxypeptidase may be a main anti-inflammatory agent of aloe, though other compounds could contribute to the effect 29 .

\section{Musculoskeletal system:}

Aloe is also beneficial in Wajaul Mafasil (Joints Pain). It mixed with roghan gulab and used as a Tila in Wajaul Mafasil $6,9,10,22,23,24$.

\section{DOSE:}

6 gm, $234 \frac{1}{2}$ g- 9g, $9 \quad 1$ ratti-4 ratti, 7,8 31/2 masha- $41 / 2$ masha, 13

1.75 masha-31/2 masha, 7 masha, 101/2 masha 22

SUBSTITUTE (BADAL):

Turbud (Ipomoea turpethum R.) 7,8

Usara Rewand 7

Huzuz double its weight, says Ibn-e-Masawaih 5

Rasoot double its weight, and Afsanteen, Zafraan 22

\section{CHEMISTRY:}

The aloe yields two important products:

Aloe resin: It is the solid residue obtained by evaporating the latex obtained from the pericyclic cells beneath the skin. The bitter yellow latex contains the anthroquinone barbaloin (a glucoside of aloe-emodin) and iso- barbaloin in addition to a series of 0 - glucosides of barbaloin called aloinosides chrysophanic acid, and upto $63 \%$ resin. Filtering out resins from the exudates and concentrating the remaining anthroglycoside material into crystalline form produces aloin. The concentration of anthroglycosides varies with the types of aloe ranging from 4.5 to $25 \%$ of aloin. Aloin is a mixture of water soluble glycosides obtained from aloe 30 .

Dried leaf juice:

Anthranoids: Anthrones mainly the c-glycosides, aloins A and $\mathrm{B}$ (Barbaloin, isobarbaloin, and stereoisomers of 10-glucosylaloe-emodin anthrone), other glycosides include 8-0-methyl7-hydroxy aloins A and B, aloinosides A and B (aloin-11-0rhamnosoids). Small quantities of 1, 8-dihydroxyxanthraquinoid glycones, including aloe-emodin and chrysophanol are present 11 .

Chromones: Major constituents are aloesin and aloeresin E. Lesser quantities of isoaloresin D, 8-c-glucosyl-7-o-methylaloesol and related glycosides which may be esterified at the glucose moiety by either cinnamic, p-coumeric or ferulic acids are also present. Non-glycosylated chromones include 7-hydroxy-2, 5-dimethyl chromone, furoaloesone, 2acetonyl-7-hydroxy-8-5-methyl chromone and 2-acetonyl-87-hydroxy-5-methyl chromone ${ }^{11}$.

Phenyl pyrones- glycosides include aloenin and aloenin B ${ }^{11}$.

Other constituents- Cinnamic acid and 1-methyl tetralin, salicylates, cholesterol, .tryglycerides, magnesium lactate, carboxypeptide 11,31 .

\section{TOXICOLOGY:}

Harmful (Muzir): It is harmful to intestine due to its erosive property $7,8,23$. 
Corrective (Musleh): 7,8,23

Kateera (Sterculia urenus)

Gul-e-surkh (Rosa Damascus mill)

\section{Side effects:}

- Gastrointestinal: Spasm, Irreversible intestinal mucosa damage, hemorrhagic diarrhea due to internal use of dried juice, and pigmentation of intestinal mucosa (pseudomelanosis coli). These side effects usually resolved after withdrawal 11,21,32,33,34.

- Genitourinary: Red-colored urine, nephrotoxicity due to use of dried juice internally 11,34 .

- Skin: Contact sensitivity, severe burning sensation, itching, rash, pruritis after the application of Aloe Vera to skin 33 .

- Aloe can reportedly cause muscle weakness, cardiac arrhythmias, peripheral edema, and weight loss 33 .

- Reproductive: Uterine contraction causes spontaneous abortion, premature labor (internal use of dried juice). Aloe has been associated with congenital malformations, thus its use is contraindicated in pregnant and nursing women 35 .

\section{Contraindications:}

- Dried aloe juice should not be used internally in case of pregnancy and lactation because anthraquinone is secreted in breast milk 21,32,31,34.

- It is Contraindicated in patients with kidney disease, cardiac disease, bowel obstruction, IBS and appendicitis 32,31 .

- It should not be used topically on deep wounds. ${ }^{211}$

- It should not be used topically by persons who are hypersensitive to this plant or plants in the LIliaceae family such as garlic, onions etc ${ }^{32}$.

\section{Interactions:}

\section{Herb/Drug}

- Aloe product taken internally may increase the effects of antidysrhythmics (e.g. quinidine), cardiac glycosides, loop diuretics, potassium wasting drugs, thiazide diuretics 32,34 .

Herb

- The action of jimsonweed is increased in case of chronic use of aloe.

- Licorice may cause hypokalemia when used with aloe or taken internally 32 .

\section{MURAKKABAT 7,8,23}

Habb-e-tinkar

Habb-e-shibyar

Habb-e-mudir

Habb-e-sibr

Habb-e-ayarij

\section{CONCLUSION:}

In last few decades, there is increased interest in understanding the mechanism of action and development of herbal drugs for wellness of human being. Treatment based on allopathic drugs is effective in the prevention and management of diseases, but it is very expensive and has a lot of adverse effects. Hence, the implication natural herbal drugs in prevention and management of diseases, day by day are increasing all over the world, especially in the developing countries, due to their affordability and less toxicity. The $A$. barbadensis Linn (Sibr) has been used by renowned Unani Physicians since ancient time to treat various bacterial infection, gastro-intestinal disorders, skin conditions, fighting against allergies, to heal cancer, and boosting the immune system. Along with this, Sibr has many other uses which are supported by various researches done by researchers across the world.Traditionally, A. barbadensis Linn is used to treat a huge variety of health problems. Consequently, there is a burning call for investigate the biological activity of its phytoconstituents for development of a new more effective, economical, reliable herbal drug with better efficacy and higher safety margin.

\section{ACKNOWLEDGEMENT:}

The authors were thankful to Prof. Misbahuddin Siddiqi, D/o Moalijat, Faculty of Unani medicine, A.M.U., Aligarh-202002 for providing necessary support to carry out this work.

\section{CONFLICT OF INTEREST:}

There is no any conflict of interest to declare.

\section{REFERENCES:}

1. Sajjad A., Sajjad S.S, "Aloe vera: An Ancient Herb for Modern Dentistry- A Literature Review" Journal of Dental Surgery, 2014; 1-6.

2. Pandey A., Singh S, "Aloe Vera: A systemic Review of its Industrial and Ethno-Medicinal Efficacy" Int. J. Pharm. Res. Allied Sci., 2016; 5(1):21-33.

3. Surjushe A., Vasani R., Saple D.G, "Aloe Vera: A Short Review" Indian Journal of Dermatology" 2008; 53 (4):163- 166.

4. Kumari B.N., Sharmila N, "Aloe vera its medicinal uses: A review" Int. J. Pharmacol. Pharm. Sci., 2015; 2(6):16-21.

5. Rhazi Z.A.B. Kitab al Abdal, English Translation. $1^{\text {st }}$ ed. New Delhi: CCRUM, Department of ISM \& H, Ministry of Health \& Family Welfare, Government of India; 1999. P.44, 46, 84, 90.

6. Ali Hakeem Syed Safiuddin. Unani Advia Mufrida. $4^{\text {th }}$ ed. New Delhi: Taraqqi Urdu Bureau; 1986. P. 58,191-192,280-281.

7. Tariq NA. Khwas-ul-advia.new Delhi: Idara Kitab-us-Shifa Kocha Chelan Daryaganj; YNM. P. 105-107,460,759-761.

8. Kabeeruddin H. Makhzanul Mufradat. New Delhi: Ejaz Publishing House Daryaganj; YNM. P. 102-103,363-364,590-591.

9. Baitar Z.A.I. Aljamiul Mufradat Al Advia Wa Al Aghzia, Urdu Translation. Vol. III. New Delhi: CCRUM Ministry of Health and Family Welfare, Government of India; 1999. P. 96-98,170-175.

10. Gupta A.K, Tandon N. Review on Indian Medicinal Plants. Vol II. New Delhi: Medicinal Plants Unit ICMR; 2004. P. 101-109.

11. Joanne B, Linda A, Anderson, David P. Herbal Medicines-A Guide for health care professionals. $2^{\text {nd }}$ ed. YNM. P. 42-46,243-249.

12. Tabri A.H.R. Firdaus-ul-Hikmat (Urdu Translation by Hakeem Rasheed Ashraf Nadwi), Vol. II. 1 $1^{\text {st }}$ ed Lahore: Idara Tarjuman Tib Diamond Publications; 1996. P. 163-164,202-203,207.

13. Rushd I. Kitab ul Kulliyat (Urdu Translation). $2^{\text {nd }}$ ed. New Delhi: CCRUM Ministry of Health and Family Welfare, Government of India; 1987. P. 260-261,320.

14. Ara Der Marderosian, John AB. The Review of Natural Products. $3^{\text {rd }}$ ed. (Fact and Comparisons); 2002. P. 25-28, 311-314,632633, 709-710.

15. Ivan AR. Medicinal Plants of the World-Chemical constituents, Traditional and Modern Medicinal Uses. Hunna Press; 1999. P. 65-79.

16. Sir J.D. Hooker, C.B.K.C.S.I. The Flora of British India. Vol. II, III, VI. Periodical Expert Book Agency; 1984. P. 246, 356, 386, 4456,525 .

17. Pekin Jr TJ, Zvaifler NJ. "Haemolytic complement in synovial fluid" J Clin Invest, 1964; 43:1372- 1382.

18. Sheshadri TR. Medicinal Plants of India. Vol. I. Indian Council of Medical Rsearch; 1976. P. 44-46, 191-192. 
19. Pareek S, Nagaraj A, Sharma P, Naidu S, Yousuf A. "Aloe-vera: A Herb With Medicinal Properties" IJOCR, 2013; 1(1):47- 50.

20. Rhazi Z.A.B.. Kitabul al Mansoori (Urdu Translation). New Delhi: CCRUM Ministry of Health and Family Welfare, Government of India; 1991. P. 136,143, 145,391-394.

21. Sharma PC, Velnu MB, Dennis TJ. Database on Medicinal Plants used in Ayurvedic. Vol I, III, V. CCRAS; 2002. P. 225-243.

22. Ghani H.N. Khazainul Advia. Part I-IV. New Delhi: Idara Kitab us shifa Daryaganj; YNM. P. 308-312, 861-862, 1352-1354.

23. Qasmi IA. Kitab-ul-Mufridat. $1^{\text {st }}$ ed. Aligarh: International Printing Press; 2001. P. 129-130, 154-155, 236-238.

24. Baghdadi I.H. Kitab Al Mukhtarat Fit Tib (Urdu Translation by CCRUM).Vol II. New Delhi: Ministry of Health and Family Welfare; 2007. P. 118,209,239-240.

25. Hakeem A.H. Bustan-ul-Mufridat. Lucknow: Khursheed Book Depot; 1991. P. 81,187,209,347,348.

26. Strickland FM, Pelley RP, "Prevention of Ultraviolet radiation and induced suppression of contact and delayed hypersensitivity by Aloe Barbadensis gel extract". J Invest dematol, 1994; 102:197-204.
27. Syed TA et al. "Management of psoriasis with Aloevera extract in a hydrophilic cream: a placebo-controlled, double-blind study" Trop Med Int Health, 1996; 1:505.

28. Gupta K. "Aloes Compound (an herbal drug) in functional sterility" XVI. Indian Obst.Gynae, 1972; 19.

29. Albert Y. Leung, Steven Foster. Encyclopedia of Common Natural Ingredients used in Food, Drugs and Cosmetics. $2^{\text {nd }}$ ed. A WileyInter science Publication; 1996. P. 25-28,271-274,551-552.

30. Leung AY. Encyclopedia of common Natural Ingredients Used in Food, Drugs and Cosmetics. New York: J Wiley and Sons; 1980. P. 45-47.

31. Chun-su-Yuan, Eric J, Brent A. Textbook of Complementary and Alternative Medicine. II ed. Informa Healthcare; 2006: $13,14,43,472,559,560,638,657,667$.

32. Linda S.R. Mosby's Handbook of Herbs and Natural Supplements. 2001. P. 25-31, 370-375, 745-748.

33. Aronson JK. Meyler;s Side Effects of Herbal Medicines. Elsevier Saunders; 2009. P. 39,154.

34. Charles W. Fetrow, Juan R. Avita. The Complete Guide to Herbal Medicines. Springhouse: Corporation; 2002. P. 21-23, 210-211, 423-424.

35. Briggs C. "Herbal medicine: Aloe" Can Pharm J, 1995; 128:48-50. 